stations might be linked together so that the peak load might be distributed more evenly, shows how seriously engineers regard the problem. Where Nature makes it possible to collect large quantities of wates by the building of dams across valleys and utilising the supplementary energy of hydraulic power stations for yearly storage, the peak demands may be economically covered for months. If the capacity is not sufficient, it can be augmented by using storage pumps to utilise the surplus energy available at night time. In many cases the initial costs of these methods are prohibitive. In the Escher-Wyss News for June, published by the EscherWyss Engineering Works, Ltd., of Zurich, Dr. Marguerre describes his thermal process for storing surplus energy. The principle may be explained by comparing it to that of a hydraulic pumping storage plant. In this plant, water is pumped from a low to a high level by utilising surplus energy. This energy is then recovered when required by allowing the water to fall to the lower level. In the thermodynamic method, heat is pumped from a low to a high temperature by means of the heat pump (turbocompressor) and the energy recovered in a steam turbine by a similar ternperature drop. The efficiency under average conditions is about 50 per cent. The costs are worked out for practical cases. The method can be used advantageously in connexion with town heating services

\section{Water Heating by Electricity}

Is order that heating water by electricity may be an economic proposition, it is necessary that electricity be sufficiently cheap. If the price is less than a penny per unit, the method is worth considering. A recent estimate made by the British Electrical Development Association of 2 Savoy Hill, W.C.2, shows that there are already two million houses in Great Britain connected to the supply mains in areas where electricity is offered at the price of $\frac{3}{13} d$. per unit. The Association issues a pamphlet in which it shows that electricity provides an excellent hot water service and that the supply of hot water reduces very appreciably household drudgery. When hire or hire-purchase terms are available, there is little capital outlay. Prospective users are advised to call at electricity show-rooms and builders are encouraged to make provision for electric hot water systems in new houses. In France, the Societe pour le Developpement des Applications de l'Electricité has recently estimated that the number of storage water heating appliances in France exceeds 20,500. There are, however, only 81 with a capacity equal to, or exceeding, 1,000 litres.

\section{Home-Grown Timber in Great Britain}

The Inter-Departmental Committee in homegrown timber appointed by the Forestry Commissioners in December 1931 has issued an interim report (Forestry Commission. Interim Report of the Inter-Departmental Home-Grown Timber Committee, 1933. London: H.M. Stationery Office. 4d. net). The terms of reference were: "To investigate and submit proposals for improvement in the utilisation of home-grown timber". The report states that the appointment of the committee arose out of the urgent need of redressing to some extent the adverse balance of trade in Great Britain by the increased use of home-grown products. The Committee believes that with adequate organisation and a measure of protection, there should be a greatly increased use of home timber, employing some thousands of men and replacing a part of the imports from foreign countries.

THE report now available gives the area which is classified as woodland in Great Britain as nearly $3,000,000$ acres (the accepted area before the War), of which some 300,000 acres are under State management, including 230,000 acres of young plantations made by the Forestry Commission since 1920. Approximately 2,700,000 acres are private property. On most private estates, forestry is said to be now at a low ebb, from causes well known and often recapitulated. The marketing of timber forms one of the subjects commented upon by the Committee. The want of any co-ordinated system and the high costs of transport, partly-but only partly-an outcome of the absence of any definite system, have for long been subjects of discussion and complaint. The Committee recognises that if railway rates are to be lowered a guaranteed quantity of traffic is necessary, which in the past has not been forth. coming. The Report states that the immediate problem the Committee has to face is concerned mainly with the utilisation of timber of small size and low quality which will not stand heavy haulage and conversion costs. It is suggested that the smaller estates "should market their timber through a central organisation in touch with various trades using wood, and guarantee a regular supply".

\section{Radio Communication in Mines}

THe August number of the Transactions of the Mining and Geological Institute of India is to hand. Most of the papers in it are of interest mainly to those engaged in mining work in India, but the first paper, by P.I. Keith-Murray on radio communication applied to mines, is of more general interest. The author has devoted considerable attention to the subject of radio communication, and has investigated in some detail the various methods with regard to their applicability to mining purposes, and more especially to mine rescue work. He has come to the definite conclusion that, so far, no place has been found for it in this work, but he also states that in view of the rapid development of all branches it would be unwise to make any definite statement as regards the impossibility of ever employing it in the future. He shows that a great deal of important work has been and is being done, and that new methods are being evolved at a tolerably rapid rate, and appears to hope that within a measurable distance one or other of these methods may be employed for underground work, though he points out fairly enough the very serious obstacles that it application would present. 